\title{
SYSTEMATIC REVIEW: THE MAIN METHODS OF RESTITUTION OF DEGRADED AREAS IN THE CERRADO
}

\author{
REVISÃO SISTEMÁTICA DOS PRINCIPAIS MÉTODOS DE RESTITUIÇÃO DE ÁREAS \\ DEGRADADAS DO CERRADO
}

\author{
Gabrielli de Almeida Santos ${ }^{1}$, Jaçanan Eloisa de Freitas Milani ${ }^{1}$ \\ ${ }^{1}$ Universidade Federal de Mato Grosso, Cuiabá, Mato Grosso, Brasil - \\ gabriellidealmeidasantos@gmail.com \& jacanan.milani@gmail.com
}

\begin{abstract}
The Cerrado occupies $24 \%$ of the Brazilian territory, half Amazon extension, and despite having the richest flora among the world's savannas, it has been suffering deforestation rates as same as Amazon. Consequently, it is estimated that $57 \%$ of Cerrado is degraded. In this context, the present paper aimed to accomplish a systematic review of the last 10 years which answered the following question: "what are the main methods of restitution of degraded areas in the Cerrado?". Therefore, the methodology was divided into 5 stages: papers identification in the research platform Google Scholar; title screening to exclude duplicates; variable eligibility; inclusion and analysis. Within the 44 analyzed papers, the biggest amount of publication occurred in 2011. Distrito Federal, Minas Gerais e Mato Grosso do Sul were the states with more publications. The most studied Cerrado physiognomic vegetation was the Cerrado sensu stricto. Active restitution was the most abundant. $80 \%$ of the papers were labelled as restoration and the rest as recovery. Based on this study it is conclude that the most used restitution method in the Cerrado degraded areas was the active restoration with drift planting and direct seeding.
\end{abstract}

KEYWORDS: Brazilian savana, Degradation, Recovery, Restoration.

RESUMO

O Cerrado ocupa $24 \%$ do território brasileiro, metade da extensão da Amazônia, e, mesmo possuindo a flora mais rica entre as savanas mundiais, vem sofrendo taxas de desmatamento no mesmo nível desta. Por consequência, estimase que $57 \%$ do bioma encontra-se degradado. Nesse contexto, o presente trabalho objetivou realizar uma revisão sistemática dos últimos 10 anos que respondesse a seguinte pergunta: 'quais os principais métodos de restituição de áreas degradas do Cerrado?'. Para tanto, a metodologia foi dividida em 5 etapas: identificação dos artigos de interesse na plataforma de pesquisa Google Scholar; triagem dos artigos escolhidos apenas pela leitura do título para exclusão de duplicatas; elegibilidade das variáveis de interesse; inclusão dos artigos e análise. Entre os 44 artigos analisados, o maior volume de publicações ocorreu em 2011. Distrito Federal, Minas Gerais e Mato Grosso do Sul foram os estados que mais publicaram. A fitofisionomia mais estudada foi o Cerrado sensu stricto. Restituição ativa foi mais abundante. $80 \%$ dos artigos foram classificados como restauração e o restante como recuperação. Com este estudo conclui-se que o método mais utilizado para restituição do Cerrado foi a restauração ativa com plantio de mudas e semeadura direta.

PALAVRAS-CHAVE: Savana brasileira, Degradação, Recuperação, Restauração. 


\section{INTRODUCTION}

The current development system has been the main subject of environmental degradation once the unprecedented consumerism and exploitation caused worrying levels of pollution, biodiversity destruction, rapid depletion of mineral reserves and others natural resources all around the world (MARCATTO, 2002).

As a strategy to reduce environmental degradation, the Bonn Challenge is a global effort for restitution of 150 million hectares of degraded and deforest areas all over the world (IUNC, 2020). Brazil has compromised to restore 13 million hectares until 2030 (BENINI \& ADEODATO, 2017). According to the current Brazilian legislation, when adding up PPA (Permanent Preservation Area) and LR (Legal Reserve) areas that need to be restored, there is a deficit of approximately 21 million hectares of nonrestored areas (SAE, 2013) in which about 8 million concentrates in Amazon, 6 million in Atlantic Forest and 5 million in Cerrado.

Priority actions to restore are expected to areas considered as 'hostpots'. This term was originally conceived by Norman Myers in 1988. The definition uses the notion of endemism as a biological criterion for priority-setting purposes (MYERS, 2003), i.e., a local is considered as 'hotspots' when it owns a high concentration of species linked with a high endemism level and suffer an exceptional extinction threat (MYERS, 1988).

In this context, the Cerrado Biome, for being considered the richest flora within the world savannas (>7,000 species) (KLINK \& MACHADO, 2005) by holding $5 \%$ of global biodiversity and for owning a high level of endemism with an average annual deforest of $9,9 \mathrm{~km}^{2}$ in the last decade (MACHADO et al., 2004; INPE, 2020), is labelled as 'hotspots' to the global biodiversity conservation (KLINK \& MACHADO, 2005).

With an original area of 2 million $\mathrm{km}^{2}$, Cerrado has already lost over $48 \%$ of extension only from 2002 to 2008 (VIANA, 2013). If its average annual rate of deforest persists, Machado et al. (2004) predict the Cerrado Biome extinction in 2030. However, its conservations efforts are much lower than those targeted to the Amazon since the Cerrado legal reserve percentage corresponds to $1 / 4$ of Amazon's percentage (MMA, 2014).

Furthermore, only $8.21 \%$ of Cerrado is protected by law, such fact is aggravated due to $20 \%$ of the endemic or threatened species are not present in those locations (KLINK \& MACHADO, 2005).

In contrast, the technical framework used to degrade areas restitution has been current growing. The restitution concepts and methods evolution allowed the transition from a simplistic context of a simple application of agroforestry techniques to more complex models which considers the interactions between specie/individual and ecological aspects of each species in addition to environmental functionality, which contributed to the success of projects in this nature (LIMA \& MILANI, 2017).

The main restitution techniques are categorized in two ways: active and passive. The passive has its base influenced by the successional theory. The successional processes start from the assumption that the environmental would naturally trigger a successional process, i.e., a natural regeneration, when it has suffered any perturbation. The active, in its turn, explores the vegetation establishment and favoring, either using techniques as nucleation, litter or seed banks transposition, drift planting, artificial perches, etc. Choosing the properly technique depends on the degradation degree and on the ecosystem kind (LIMA \& MILANI, 2017).

In that light, it is understood that the Cerrado Biome is a priority for restitution. Nonetheless, to restore it, initially it is needed a theoretical and practical foundation, for only the experimental knowledge can head the public policy of environmental restore. Therefore, this paper aimed to develop a systematic review whose purpose is to answer the following question: "What are the main methods of restitution of degraded areas in the Cerrado?".

\section{MATERIAL E METHODS}

For this work preparation the systematic review method was used, which consists of a planned process to answer a question through identification, selection and critical evaluation of studies, data collect, analysis and data presentation, and results presentation (ATALLAH \& CASTRO, 1998).

The methodology was divided into 5 stages: papers of interest identification in a research platform, title screening to exclude duplicates, variable eligibility, papers inclusion, and analysis (Fig. 1).

The searches were made on august 2020, in the scientific research platform Google Scholar. As search descriptors, it was used the succeeding keywords: "Cerrado"; "áreas degradadas"; "recuperação de áreas degradadas"; "restauração de áreas degradadas"; "restauração ativa"; "restauração passiva". They were used exclusively with the boolean operators "AND" and "OR" (MENEZES et al., 2020). To systematize the searches, researched by year from 2010 to 2020, considering only up 
to the 20th page suggested by the search engine, since, after that, the interested papers became sparse. After the initial selection by only reading the titles, a crossover of these was made to exclude the duplicates, so then the abstracts were read.

For the methodology validation (Fig. 1), articles were considered published only in journals fully available in English or Portuguese, that described the restitution methods used for the recovery/restoration of degraded areas of the different types of vegetation in the Cerrado biome. However, reviews, editorials, letter to editor, comments, news, dissertations, final papers, and papers that did not use the species scientific names were excluded. The variables analyzed were author, publication year, location, physiognomic vegetation, restitution method, plant species, method type (active or passive) and the journal in which it was published.

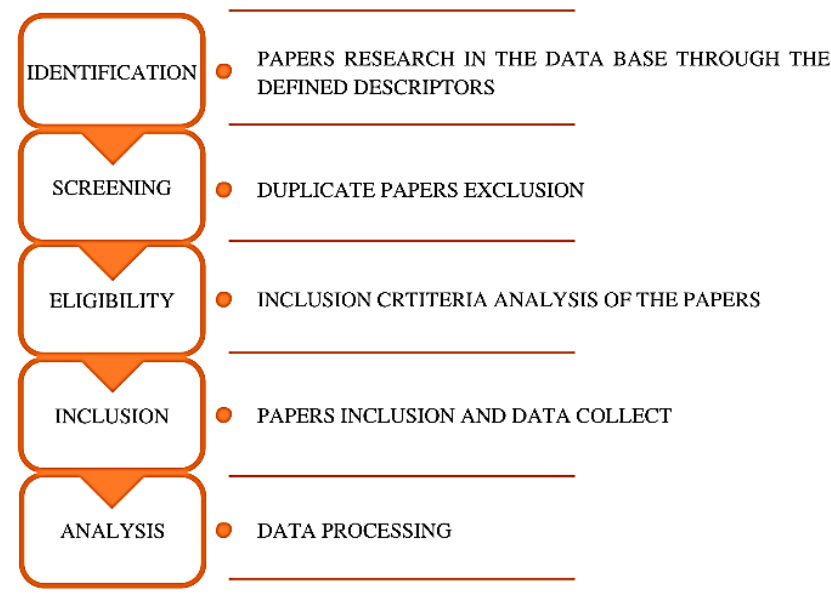

Figure 1. Methodology flowchart adapted from Menezes et al. (2020).

For this paper, the term "restitution" was used to refer to both restoration and recovery concepts. At the end, the methods were identified as "recovery" or "restoration" in consonance with the definition given by the Brazilian Federal Law no.9.985 (BRASIL, 2000):

Article 2 (...)

(...)

XIII - recovery: ecosystem or degraded wild population restitution to a non-degraded condition, in which can be different from its original situation;

XIV - restoration: ecosystem or degraded wild population restitution to the closest condition as possible to its original situation;

(...)

\section{RESULTS AND DISCUSSIONS}

Ciência Florestal, Hoehnea e Neotropical Biology and Conservation were the journals with the greatest adherence to the theme with the higher number of published papers. Their respectively Qualis/CAPES classification are B1, B4, and B5 in the 2013-2016 rating.

Considering the analyzed variable, the quantity of papers is described in Table 1.

Table 1. Number of papers on each stage.

\begin{tabular}{cc}
\hline Stage & Number of papers \\
\hline Title reading & 330 \\
\hline Abstract reading & 52 \\
Papers included & 44 \\
\hline
\end{tabular}

Over the decade evaluated, the largest amount of publication occurred in 2011 with 8 published papers. Although the Cerrado is comprehended by the Federal Units: Bahia, Distrito Federal, Goiás, Maranhão, Mato Grosso, Mato Grosso do Sul, Minas Gerais, Paraná, Piauí, Rondônia, São Paulo, Tocantins and further on the entrances in Amapá, Amazonas, and Roraima (MMA, s.d.), the studies were conducted only in the following locations: Distrito Federal (DF), Minas Gerais (MG), Mato Grosso do Sul (MS), Goiás (GO), Mato Grosso (MT), São Paulo (SP), Piauí (PI), and Tocantins (TO). DF, MG, and MS published the biggest number of papers: 12,10 and 8 , whereas GO, MT, SP, PI, and TO published: 6, 5, 1, 1. and 1 respectively.

According to the Figure 2, the most studied physiognomic vegetation by the most representative Federal Units was the 'Cerrado s.s.', once 'Cerrado' refers to papers that did not specify the location's physiognomic vegetation either by lack of trace elements which indicates the region composition or by lack of details.

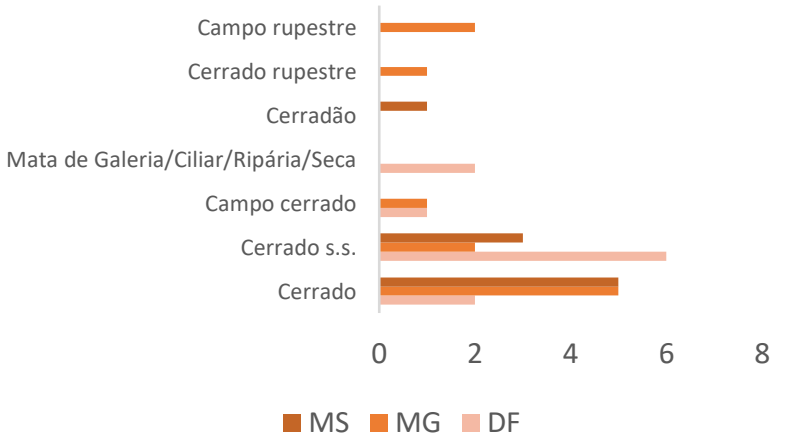

Figure 2. Distribution of physiognomic vegetations in Mato Grosso do Sul (MS), Minas Gerais (MG) and Distrito Federal (DF). 
The Figure 2 shows a high discrepancy in the studies distribution over the physiognomic vegetations, which suggest a lack of studies in these areas. It may indicate that areas not studied are in a less intense degradation state.

As for the type of method used, active restitution was the most abundant during the period analyzed (Figure 3).

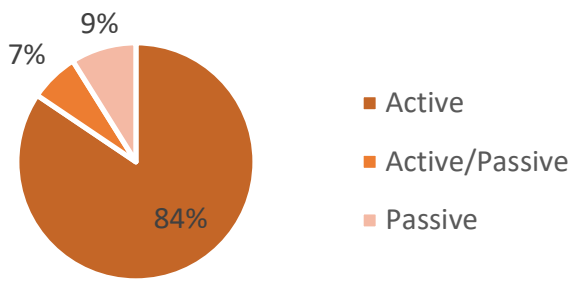

Figure 3. Distribution of restitution type over the analyzed decade.

About $20 \%(n=9)$ of the papers were labelled as "recovery" and the most applied method was drift planting, in wich Canavalia ensiformis (L.) DC was more quoted, for this specie is highly recommended to green manure (RODRIGUES et al., 2004).

$80 \%$ of the papers were labelled as "restoration", in which the drift planting was more applied, followed by direct seeding. Copaifera langsdorfii Desf., Dipteryx alata Vog., Myracrodruon urundeuva (M. Allemão) Engl., Enterolobium contortisiliquum (Vell.) Morong, Guazuma ulmifolia Lam. were the most used species, respectively. The use of $C$. langsforfii, D. alata, and E. contortisiliquum can be justified by the fact that these species belong to the Fabaceae, which is widely used for the purpose of green manure due to its association capacity with nitrogen fixation bacteria along with being capable of accumulate this by the biological fixation (SILVA et al., 2009). Differently, G. ulmifolia was used for its essentially zoochoric dispersal (CARVALHO, 2007). Lastly, the use of $M$. urundueva was due to its rapid development, for although it is considered as a secondary succession specie (PAREYN, 2018), it can grow along with pioneers (BERTONI \& DICKFELDT, 2007).

Regardless of the term used, there is a prevalence of active method for Cerrado environments restitution, even though, accordingly with Adeodato (2016), passive restitution is the solution to $32 \%$ of the Cerrado degraded areas and only $22 \%$ needs active methods. This scenario is due to the high resilience of the Cerrado litter seeds, facilitating the natural regeneration. Consequently, the active method as drift planting or direct seeding is only recommended when the soil is turned over and destroyed along with the genetic seed bank (ADEODATO, 2016).

\section{CONCLUSIONS}

With this study, it is concluded that the most used restitution methods in the Cerrado degrades areas are active restoration with drift planting followed by direct seeding.

In addition, a study deficiency of the Cerrado physiognomic vegetation other than Cerrado s.s. is implicit, as well as a study deficiency on the 20 Federal Units, since only 8 Units have developed studies. Hence, further details are recommended along with studies in all the 20 Federal Units, to promote public restitution policies and contribute to the Cerrado restitution knowledge.

\section{REFERENCES}

ADEODATO, S. Bravo resistente. Página 22, n. 103, p.4-7, 2016.

ATALLAH, A.N.; CASTRO, A.A. Revisão sistemática da literatura e metanálise. Medicina baseada em evidências: fundamentos da pesquisa clínica. São Paulo: Lemos-Editorial, 1998.

BENINI, R.M.; ADEODATO, S. Economia da restauração florestal, São Paulo: The Nature Conservancy, 2017.

BERTONI, J.E.A.; DICKFELDT, E.P. Plantio de Myracrodruon urundeuva Fr. All. (aroeira) em área alterada de floresta: desenvolvimento das mudas e restauração florestal. Revista do Instituto Florestal, v.19, n.1, p.31-38, 2007.

BRASIL. Lei no 9.985, de 18 de julho de 2000. Diário Oficial da União, Brasília, 2000. Disponível em: http://www.planalto. gov.br/ccivil_03/leis/19985.htm

CARVALHO, P.E.R. et al. Guazuma ulmifolia. Circular TécnicaEmbrapa Florestas, n.141, 2007.

INPE - INSTITUTO NACIONAL DE PESQUISAS ESPACIAIS. Coordenação Geral de Observação da Terra. TerraBrasilis, 2020. Disponível em: http://terrabrasilis.dpi.inpe.br/

IUNC - INTERNATIONAL UNION FOR CONSERVATION OF NATURE. Restore Our Future: Bonn Challenge. 2000. Disponível em: https://www.bonnchallenge.org/about

KLINK, C.A.; MACHADO, R.B.A conservação do Cerrado brasileiro. Megadiversidade, v.1, n.1, p.147-155, 2005.

LIMA, E.M.; MILANI, J.E.F. Restauração de áreas degradadas. 1a Semana de Aperfeiçoamento em Engenharia Florestal da UFPR. Curitiba: UFPR, 2017. Disponível em: https://www.even3.com.br/anais/iseaflor/59451-RESTAURACAO -DE-AREAS-DEGRADADAS

MACHADO, R. et al. Estimativas de perda da área do Cerrado brasileiro. Brasília: Conservação Internacional, 2004.

MARCATTO, C. Educação ambiental: conceitos e princípios. Belo Horizonte: FEAM, 2002. 
MENEZES, C.R. et al. Efetividade e toxicidade da cloroquina e da hidroxicloroquina associada (ou não) à azitromicina para tratamento da COVID-19. O que sabemos até o momento? Journal of Health \& Biological Sciences, v.8, n.1, p.1-9, 2020.

MMA - MINISTÉRIO DO MEIO AMBIENTE. Biomas. s.d. Disponível em: https://antigo.mma.gov.br/biomas/cerrado

MMA - MINISTÉRIO DO MEIO AMBIENTE. PPCerrado - Plano de Ação para prevenção e controle do desmatamento e das queimadas no Cerrado: 2a fase (2014-2015). Brasília: MMA, 2014.

MYERS, N. Threatened biotas:" hot spots" in tropical forests. Environmentalist, v.8, n.3, p.187-208, 1988.

MYERS, N. Biodiversity hotspots revisited. BioScience, v.53, n.10, p.16-917, 2003.

PAREYN, F.G.C. et al. Myracrodruon urundeuva: Aroeira. Embrapa Semiárido-Capítulo em livro técnico (INFOTECA-E), 2018.

RODRIGUES, J.E.L.F. et al. A importância do feijão de porco (Canavalia ensiformis DC) como cultura intercalar em rotação com milho e feijão caupi em cultivo de coqueirais no município de Ponta-de-Pedras/Marajó-PA. Embrapa Amazônia Oriental, 2004.

SAE - SECRETARIA DE ASSUNTOS ESTRATÉGICOS. Impacto da revisão do código florestal: como viabilizar o grande desafio adiante? 2013. Disponível em: https://www.socioambiental.org/ sites/blog.socioambiental.org/files/nsa/arquivos/artigo-codigoflorestal_britaldo_soares_sae_2013pdf.pdf

SILVA, P.C.G. et al. Fitomassa e relação $\mathrm{C} / \mathrm{N}$ em consórcios de sorgo e milho com espécies de cobertura. Pesquisa Agropecuária Brasileira, v.44, n.11, p.1504-1512, 2009.

VIANA, S. Projeto de Monitoramento e do Desmatamento nos Biomas Brasileiros por Satélite. 20 Seminário técnico-científico de análise dos dados do desmatamento na Amazônia LegalPRODES, 2013. 